\title{
Apoptosis rate and transcriptional response of pancreatic islets exposed to the PPAR gamma agonist Pioglitazone
}

\author{
Rodrigo N Lamounier ${ }^{1,2+}$, Cassio N Coimbra ${ }^{1,3+}$, Peter White ${ }^{2}$, Flavia L Costal ${ }^{1}$, Leonardo S Oliveira ${ }^{1,3}$, \\ Daniel Giannella-Neto ${ }^{4}$, Klaus H Kaestner ${ }^{2^{* *}}$ and Maria Lúcia Corrêa-Giannella ${ }^{1 *+}$
}

\begin{abstract}
To explore the molecular pathways underlying thiazolidinediones effects on pancreatic islets in conditions mimicking normo- and hyperglycemia, apoptosis rate and transcriptional response to Pioglitazone at both physiological and supraphysiological glucose concentrations were evaluated. Adult rat islets were cultured at physiological $(5.6 \mathrm{mM})$ and supraphysiological $(23 \mathrm{mM})$ glucose concentrations in presence of $10 \mu \mathrm{M}$ Pioglitazone or vehicle. RNA expression profiling was evaluated with the PancChip 13k cDNA microarray after 24-h, and expression results for some selected genes were validated by qRT-PCR. The effects of Pioglitazone were investigated regarding apoptosis rate after 24-, 48- and 72-h. At $5.6 \mathrm{mM}$ glucose, 101 genes were modulated by Pioglitazone, while 1,235 genes were affected at $23 \mathrm{mM}$ glucose. Gene networks related to lipid metabolism were identified as altered by Pioglitazone at both glucose concentrations. At $23 \mathrm{mM}$ glucose, cell cycle and cell death pathways were significantly regulated as well. At $5.6 \mathrm{mM}$ glucose, Pioglitazone elicited a transient reduction in islets apoptosis rate while at $23 \mathrm{mM}, \mathrm{Bc} / 2$ expression was reduced and apoptosis rate was increased by Pioglitazone. Our data demonstrate that the effect of Pioglitazone on gene expression profile and apoptosis rate depends on the glucose concentration. The modulation of genes related to cell death and the increased apoptosis rate observed at supraphysiological glucose concentration raise concerns about Pioglitazone's direct effects in conditions of hyperglycemia and reinforce the necessity of additional studies designed to evaluate TZDs effects on the preservation of $\beta$-cell function in situations where glucotoxicity might be more relevant than lipotoxicity.
\end{abstract}

Keywords: PPARy, Pioglitazone, Islets, Gene expression, Apoptosis

\section{Introduction}

Type 2 diabetes is characterized by impaired insulin secretion and reduced peripheral insulin sensitivity. Loss of $\beta$-cell function causes not only the progression from the prediabetic state to overt disease, but also hastens the deterioration of metabolic control in people with type 2 diabetes [1,2]. Thiazolidinediones (TZDs), a family of peroxisome proliferator-activated receptor $\gamma$ (PPAR $\gamma)$ ligands, act by improving peripheral insulin

\footnotetext{
* Correspondence: kaestner@mail.med.upenn.edu; malugia@lim25.fm.usp.br ${ }^{\dagger}$ Equal contributors

${ }^{2}$ Department of Genetics and Institute for Diabetes, Obesity and Metabolism, University of Pennsylvania School of Medicine, 752B CRB 415 Curie Blvd., Philadelphia, Pennsylvania 19104, USA

'Laboratory for Cellular and Molecular Endocrinology LIM-25, University of Sao Paulo Medical School, Av. Dr. Arnaldo 455 \#4305, 01246-903, São Paulo, Brazil Full list of author information is available at the end of the article
}

sensitivity [3]. Clinical studies have shown that treatment with TZDs maintains $\beta$-cell function and prevents high risk patients from progressing to diabetes [4-6]. Studies in rodents demonstrated that these drugs reduce $\beta$-cell impairment and decrease islet fatty acid accumulation $[7,8]$. It is known that activation of PPAR $\gamma$ in vivo induces several peripheral adaptations that result in improved insulin sensitivity and reduced insulin demand, however, if there are direct effects such as reduced lipotoxicity $[9,10]$, protection from oxidative stress and from apoptosis [11] remains to be further investigated.

Apoptosis constitutes the main form of $\beta$-cell death [12] and gluco- and/or lipotoxicity are two of the major mechanisms for islets dysfunction and apoptosis in pancreatic cells in type 2 diabetes [13]. While TZDs have

\section{Biomed Central}


been reported to have direct beneficial effects on $\beta$-cells by preventing these toxicities $[14,15]$, by promoting antioxidative effects [16] and by preventing $\beta$-cell dysfunction under conditions of concomitant hyperglycemic and cytokine stress [17], this notion has been contested by others $[18,19]$. To further explore the molecular pathways underlying TZDs direct effects on pancreatic islets in conditions mimicking normo- and hyperglycemia, we have determined transcriptional response and apoptosis rate of rat islets to Pioglitazone, currently the only TZD in clinical use, at both physiological and supraphysiological glucose concentrations.

\section{Methods}

\section{Islets isolation and culture}

Islets were isolated from male Wistar rats (2 months of age, 220-260 g) after perfusion of the pancreatic duct, collagenase (Type V) digestion and purification on Ficoll gradients [20] and cultured in RPMI-1640 media with $10 \%$ FCS, $5.6 \mathrm{mM}$ glucose, $100 \mathrm{IU} / \mathrm{ml}$ penicillin and 100 $\mu \mathrm{g} / \mathrm{ml}$ streptomycin. All reagents were obtained from Sigma-Aldrich Chemical (St. Louis, MO, USA). All animal procedures were in accordance with NIH's 'Principles of laboratory animal care', and approved by the local ethics committee.

\section{Expression profiling}

After $24 \mathrm{~h}$ of isolation, approximately 250 islets were cultured with $10 \mu \mathrm{M}$ Pioglitazone (Takeda Pharmaceuticals, Japan) or DMSO (vehicle) for $24 \mathrm{~h}$ in either physiological (5.6 $\mathrm{mM})$ or supraphysiological $(23 \mathrm{mM})$ glucose concentrations. Both control and treated culture media contained $0.1 \%$ DMSO as a final concentration.

Two array experiments were performed in parallel to analyze the effect of Pioglitazone at both glucose concentrations (Figure 1). A direct comparison design was used, such that hybridizations were set up as Test (Cy5) vs. Control (Cy3). Five biological replicates were used for each condition.

All RNA samples were analyzed using an Agilent Bioanalyzer Lab-on-a-Chip Nano 6000 chip to determine the integrity and concentration of the samples. Only samples with a RIN factor $>6.0$ were used. Five $\mu \mathrm{g}$ of total RNA was indirectly labeled using amino-allyl dUTP and an anchored oligo $(\mathrm{dT})_{20}$ to prime reverse transcription. Methods for fluorescent labeling and data acquiring were as described [21]. The high level of sequence similarity between mouse and rat genes makes the Mouse PancChip array suitable for use with rat tissue [22]. Statistical analysis was performed in " $R$ " using both the LIMMA [23] and Statistical Analysis of Microarrays (SAM) package (http://www-stat.stanford. $\mathrm{edu} / \sim \mathrm{tibs} / \mathrm{SAM} /$ ) [24]. A one-class unpaired analysis with a False-discovery rate (FDR) of $20 \%$ was employed.

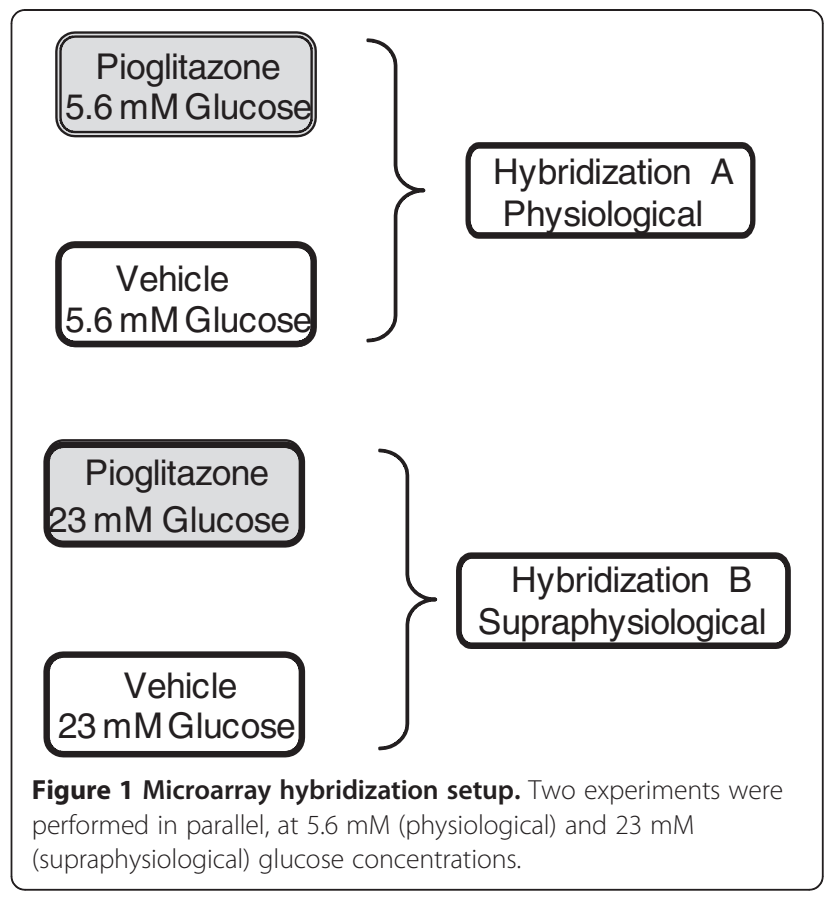

The list of significantly differentially expressed genes was filtered to remove genes with an absolute change $\leq 1.2$ fold. Microarray data are available through the Minimum Information About a Microarray Experiment (MIAME, accession number GSE40119) [25]. Biologically relevant

Table 1 Confirmation (by qRT-PCR) of gene expression changes induced by 24-hour exposure to Pioglitazone at $5.6 \mathrm{mM}$ and $23 \mathrm{mM}$ glucose concentrations

\begin{tabular}{|c|c|c|c|c|c|}
\hline & \multirow[t]{2}{*}{ Genes } & \multicolumn{2}{|c|}{ PanChip } & \multicolumn{2}{|c|}{ qRT-PCR } \\
\hline & & FC & FDR & FC & $p$-value \\
\hline \multirow[t]{5}{*}{$5.6 \mathrm{mM}$} & Fabp4 & 1.6 & 14.57 & 5.8 & 0.02 \\
\hline & Insig1 & 1.4 & 14.57 & 2.0 & 0.02 \\
\hline & Scd 1 & 1.5 & 14.57 & 1.2 & 0.32 \\
\hline & $\mathrm{Scd} 2$ & 1.4 & 14.57 & 1.9 & 0.03 \\
\hline & Sc4mol & 1.3 & 17.95 & 1.2 & 0.44 \\
\hline \multirow[t]{10}{*}{$23 \mathrm{mM}$} & $A c t b$ & 1.4 & 6.5 & 1.6 & 0.17 \\
\hline & Bad & 1.4 & 5.0 & 1.4 & 0.05 \\
\hline & Bax & 1.3 & 4.0 & 1.5 & 0.02 \\
\hline & Camk2b & 1.3 & 9.3 & 1.2 & 0.42 \\
\hline & Fabp4 & 1.4 & 4.0 & 5.0 & 0.02 \\
\hline & Hmox1 & 1.4 & 7.3 & 3.4 & 0.04 \\
\hline & Itpr2 & 1.3 & 4.0 & 1.5 & 0.04 \\
\hline & Npy & -1.3 & 2.3 & -2.7 & 0.19 \\
\hline & Prdx6 & 1.4 & 11.4 & 1.3 & 0.34 \\
\hline & Sod2 & 1.4 & 6.7 & 4.5 & 0.02 \\
\hline
\end{tabular}

Positive and negative FC (fold-change) represent, respectively, genes upregulated and downregulated by Pioglitazone. FDR: false-discovery rate. 
networks were drawn from the two lists of differentially expressed genes identified by SAM analysis. Ingenuity Pathways Analysis (www.Ingenuity.com) was employed to analyze networks affected by Pioglitazone as described [21].

Quantitative real-time reverse transcription PCR (qRT-PCR) Differential gene expression was confirmed using qRTPCR, as previously described [21] on RNA prior to amplification and using specific primers designed for rat genes (Additional file 1: Table S1). Gapdh, Actb, Hprt and $T b p$ were tested for their potential use as housekeeping genes using the geNorm analysis package [26], and Gapdh was selected as the most stable. Relative levels of mRNA expression were calculated using the $2^{\Delta \Delta C T}$ method [27]. Five independent experiments were performed in duplicate.

\section{Evaluation of apoptosis}

To evaluate the chronic effect of Pioglitazone on apoptosis, islets were cultured in RPMI-1640 with 10\% FCS and exposed or not (vehicle) for 24,48 and $72 \mathrm{~h}$ to $10 \mu \mathrm{M}$ Pioglitazone at $5.6 \mathrm{mM}$ or $23 \mathrm{mM}$ glucose. qRT-PCR was performed as described above to analyze the expression of the antiapoptotic gene $B c l 2$. The rate of apoptosis was evaluated by quantification of DNA fragmentation with the Cell Death Detection Enzyme-Linked Immunosorbent Assay Plus Kit (Roche Molecular Biochemistry, Germany). Aliquots of cytoplasmic lysates (50 islets/reaction) were analyzed and quantified using an Anthos' LUCY-3 luminometer (Anthos Labtec Instruments, Australia) at $405 \mathrm{~nm}$. Comparison of the absorbance of treated with untreated samples determined the extent of DNA fragmentation. Absorbance values from the samples were corrected for the background values and the results were expressed as arbitrary units (AU). To confirm the increased rate of apoptosis in islets exposed to Pioglitazone and $23 \mathrm{mM}$ glucose at 48 and $72 \mathrm{~h}$, caspase-3 enzyme activity was measured using the ApoTarget Caspase-3 Protease Assay Kit (BioSource International Inc, USA). Aliquots of cytoplasmic lysates (1,000 islets/reaction) were analyzed and quantified using an Anthos' LUCY- luminometer at 405

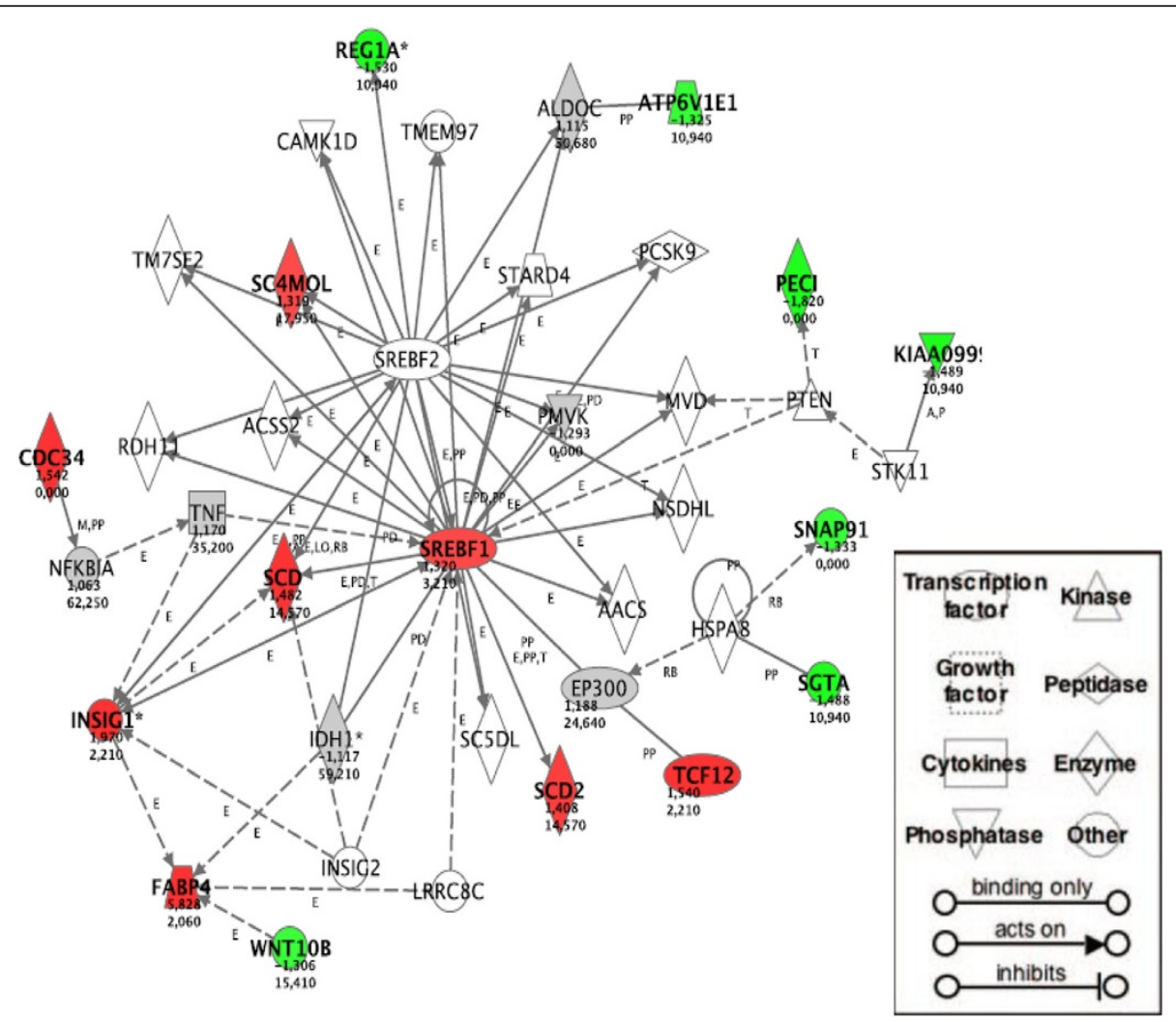

Figure 2 Pathway analysis identifies a network of genes related to lipid metabolism in islets cultured at $5.6 \mathrm{mM}$ glucose concentration. The network is displayed graphically as nodes (genes/gene products) and edges (the biological relationships between the nodes). Nodes are displayed using various shapes that represent the functional class of the gene product. The node color indicates up (red)- or down (green)-regulation by Pioglitazone. Edges are displayed with various labels that describe the nature of the relationship between the nodes (A, activation; B, binding; E, expression; I, inhibition; P, phosphorylation; T, transcription). Edges without a label represent binding only. The node Srebf1 was identified by the pathway analysis as part of the network, and its differential gene expression was determined subsequently by qRTPCR. A total of 15 differentially expressed focus genes were brought into this network with a highly significant score of 30. 
nm. Results were corrected for protein content and expressed as AU. Three independent experiments were performed in triplicate.

To rule out a toxic effect of Pioglitazone, batches of 10 islets were cultured in RPMI-1640 with 10\% FCS and exposed or not (vehicle) for $24 \mathrm{~h}$ to $10 \mu \mathrm{M}$ Pioglitazone at $5.6 \mathrm{mM}$ glucose and at $23 \mathrm{mM}$. The insulin secretory response was studied after islet incubation for $1 \mathrm{~h}$ in Kreb' s buffer with $1.6 \mathrm{mM}$ glucose for stabilization, followed by incubation for $1 \mathrm{~h}$ at 1.6 or $16.7 \mathrm{mM}$ glucose. Incubation media were collected for insulin measurement by ELISA (Linco Research, St Louis, USA). Results were corrected for DNA content and stimulation indices were calculated by dividing insulin secretion at high glucose by basal insulin secretion. Three independent experiments were performed in duplicate.

\section{Statistical analysis}

Statistical tests were performed using the JMP Version 6.0 statistical computer program (SAS Institute). The Student's $t$ test was used to confirm that the qRT-PCR results were significant and matched the direction of the fold change predicted by the array. Because assumptions for a parametric test were not valid $(\mathrm{P}<0.05$, KolmogorovSmirnov), all data concerning apoptosis rate and measurement of insulin content were evaluated by WilcoxonMann-Whitney after quantile transformation (Q), i.e., quantile data transformation is used for the construction of the quantile-quantile (Q-Q) where the values in the sample of data, in order from smallest to largest, are denoted $x(1), x(2), \ldots, x(n)$. For $i=1,2, \ldots . ., n, x(i)$ is plotted against $\mathrm{F}-1((\mathrm{i}-0.5) / \mathrm{n})$. Data were expressed as median and semi-interquartile range. Statistical significance was fixed at probability levels of $<0.05$.

\section{Results}

The transcriptional response of the islet to TZDs

The transcriptional response of pancreatic islets to Pioglitazone was determined at normal $(5.6 \mathrm{mM})$ and high $(23 \mathrm{mM})$ glucose concentrations using the PancChip microarray. Expression of 101 genes was modulated by Pioglitazone at $5.6 \mathrm{mM}$ of glucose, with

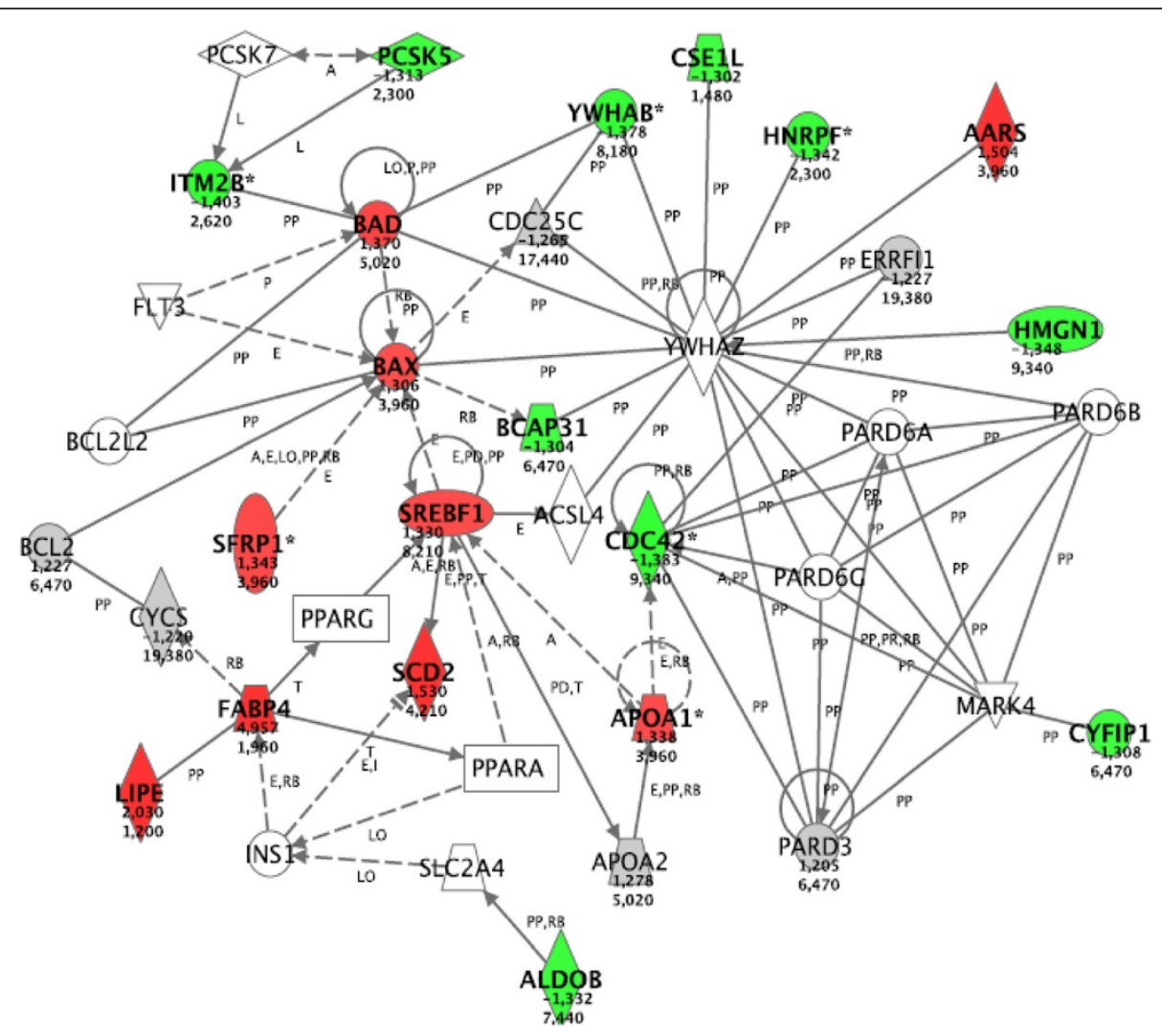

Figure 3 Network related to lipid metabolism in islets cultured at $23 \mathrm{mM}$ glucose concentration. For the explanation of the symbols and letters, see the legend to Figure 2. A total of 19 differentially expressed focus genes were brought into this network with a highly significantly score of 22. The node Srebf1 was identified by the pathway analysis as part of the network, and its differential gene expression was determined subsequently by qRT-PCR. The node Ywhaz was tested for being included in the pathway, but it was not Pioglitazone dependent. 


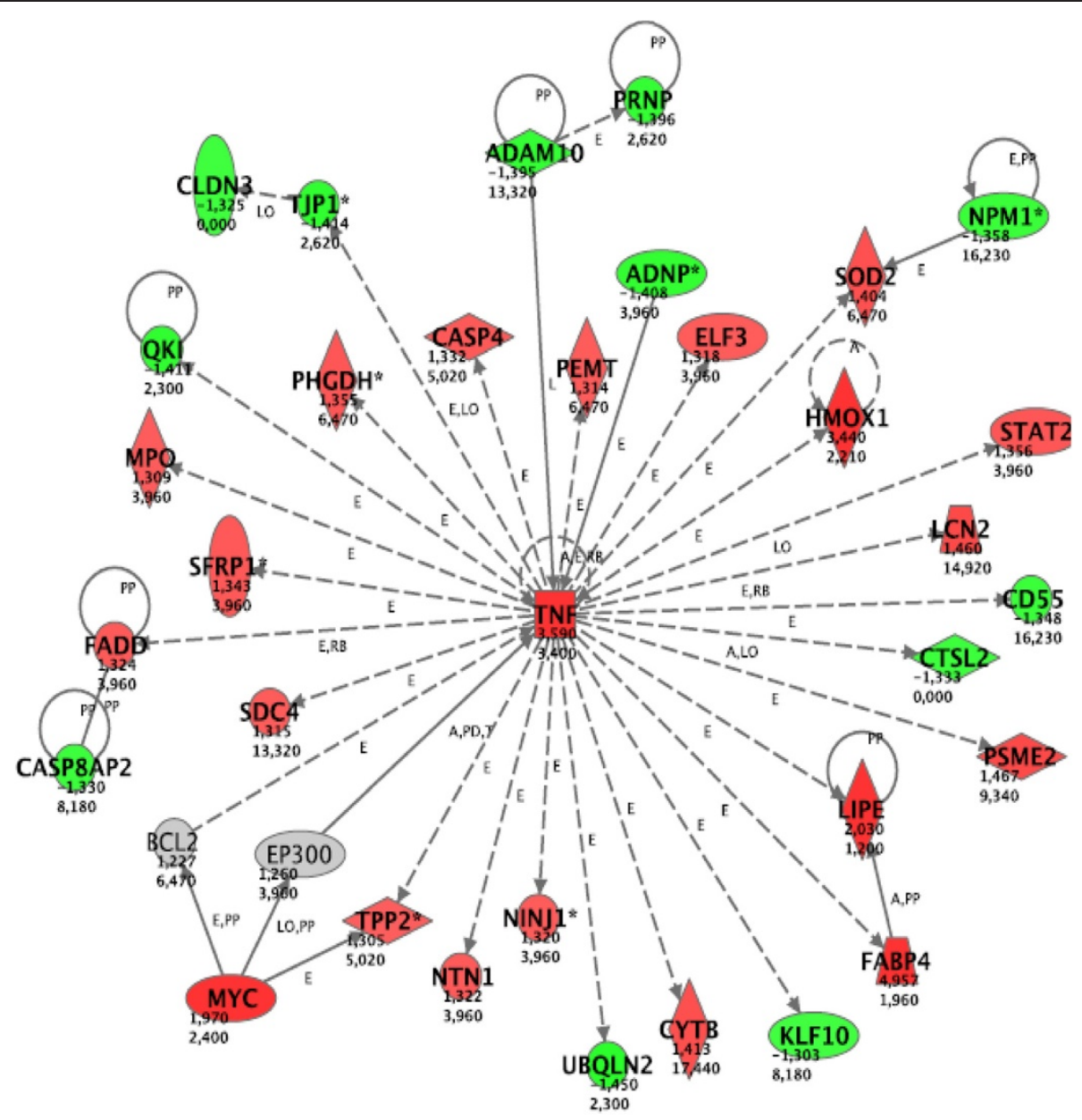

Figure 4 Network related to cell cycle and cell death in islets cultured at $\mathbf{2 3} \mathbf{m M}$ glucose concentration. For the explanation of the symbols and letters, see the legend to Figure 2. A total of 33 differentially expressed focus genes were brought into this network with a highly significant score of 60 . The three nodes Tnf, Myc and Lipe were identified by the pathway analysis as part of the network, and their differential gene expression was determined subsequently by qRT-PCR.

49 upregulated by the drug and 52 downregulated. At $23 \mathrm{mM}$ glucose 1,235 genes were affected, with 612 uregulated by the drug and 623 downregulated. The list of all genes modulated by Pioglitazone at $5.6 \mathrm{mM}$ and the list of the 200 first genes down- and up-regulated by Pioglitazone at $23 \mathrm{mM}$ are shown on Additional file 2: Tables S2 (5.6 mM) and Additional file 3: Table S3 (23 mM).

The microarray results were validated using qRT-PCR, which closely mirrored the results of the array analysis (Table 1). We also evaluated five genes previously suggested as PPARY targets, Gck, Slc2a2, Abca1, Lpl and Ucp2, as well as the expression of Pparg, Ppara, Ins1 and Ins2. None of these genes were Pioglitazone responsive in islets as determined by qRT-PCR (data not shown).

Pathway analysis indicated a single gene network, related to lipid metabolism, as Pioglitazone dependent at $5.6 \mathrm{mM}$ glucose (Figure 2). Among the differentially
Table 2 Analysis (by qRT-PCR) of the expression of additional genes identified as Pioglitazone targets by network analysis after 24-hour exposure to the drug at $5.6 \mathrm{mM}$ and $23 \mathrm{mM}$ glucose concentrations

\begin{tabular}{llcc}
\hline & Genes & FC & $\boldsymbol{p}$-value \\
\hline $5,6 \mathrm{mM}$ & Srebf1 & 1.3 & 0.02 \\
$23 \mathrm{mM}$ & Aldob & -1.8 & 0.05 \\
& Lipe & 2.0 & 0.03 \\
& Myc & 2.0 & 0.04 \\
& Scd2 & 1.5 & 0.01 \\
& Srebf1 & 1.3 & 0.03 \\
& Tnf & 3.6 & 0.05 \\
\hline
\end{tabular}

Positive and negative FC (fold-change) represent, respectively, genes upregulated and downregulated by Pioglitazone. 
Table 3 Analysis (by qRT-PCR) of the $B c / 2$ expression induced by 24-, 48- and 72- hour exposure to Pioglitazone at $5.6 \mathrm{mM}$ and $23 \mathrm{mM}$ glucose concentrations

\begin{tabular}{cccc}
\hline Glucose concentration & Time(h) & FC & $\boldsymbol{p}$-value \\
\hline $5.6 \mathrm{mM}$ & 24 & -1.2 & $\mathrm{~ns}$ \\
& 48 & -1.1 & $\mathrm{~ns}$ \\
$23 \mathrm{mM}$ & 72 & 1.0 & $\mathrm{~ns}$ \\
& 24 & -3.0 & 0.001 \\
& 48 & -2.5 & 0.002 \\
& 72 & -1.1 & $\mathrm{~ns}$ \\
\hline
\end{tabular}

Negative FC (fold-change) represents downregulation by Pioglitazone.

expressed genes included in this network six were confirmed through qRT-PCR. All genes showed the same degree and direction of change, but for $S c d 1$ and Sc4mol qRT-PCR data were not statistically significant (Table 1). At $23 \mathrm{mM}$ glucose the drug effect was much more pronounced, and consequently the number of regulated genes was dramatically increased. The two most strikingly affected networks included genes related to lipid metabolism, and cell death and cell cycle (Figures 3 and 4, respectively). Among the 10 genes selected for validation by qRT-PCR, six genes were confirmed as differentially expressed after Pioglitazone treatment (Table 1). Based upon the networks generated by our pathway analysis, we tested additional key genes by qRT-PCR. As shown in Table 2, all these genes were also Pioglitazone dependent.

\section{Evaluation of apoptosis}

The measurement of insulin secretion performed to rule out a toxic effect of Pioglitazone demonstrated that glucose-stimulated insulin secretion was not significantly different between islets exposed and not exposed to Pioglitazone for $24 \mathrm{~h}$, with stimulation indices of $2.0 \pm$ 0.3 and $1.9 \pm 0.4$, respectively, in islets maintained at 5.6 $\mathrm{mM}$ glucose and of $3.2 \pm 1.2$ and $2.1 \pm 0.9$, respectively, in islets maintained at $23 \mathrm{mM}$ glucose.

In islets cultured at $5.6 \mathrm{mM}$ glucose, $B c l 2$ RNA expression was not significantly modulated by Pioglitazone at any of the evaluated time-points (Table 3). The apoptosis rate was transiently decreased in comparison to untreated islets after $48 \mathrm{~h}$ exposure to the drug (Figure 5). At 23 $\mathrm{mM}$ glucose, $B c l 2$ RNA expression was significantly lower in islets treated with Pioglitazone for 24 and $48 \mathrm{~h}$ (Table 3 ). In agreement with the reduction of expression of this antiapoptotic gene, the apoptosis rate evaluated by DNA fragmentation (Figure 6A) and caspase-3 activity (Figure 6B) was shown to be increased by Pioglitazone after 48 and $72 \mathrm{~h}$.

\section{Discussion}

This study, designed to further investigate the direct effects of Pioglitazone on pancreatic islets, demonstrates that the effect of this TZD on islet apoptosis rate and gene expression profile depends on the glucose concentration.

Parton et al. [28] had investigated gene expression profiles of rat islets treated with a PPAR- $\gamma$ agonist (GW347845 ) only at $3 \mathrm{mM}$ glucose and found that 49 out of 9,563 genes exhibited altered expression levels. A substantial increase in the number of genes affected was

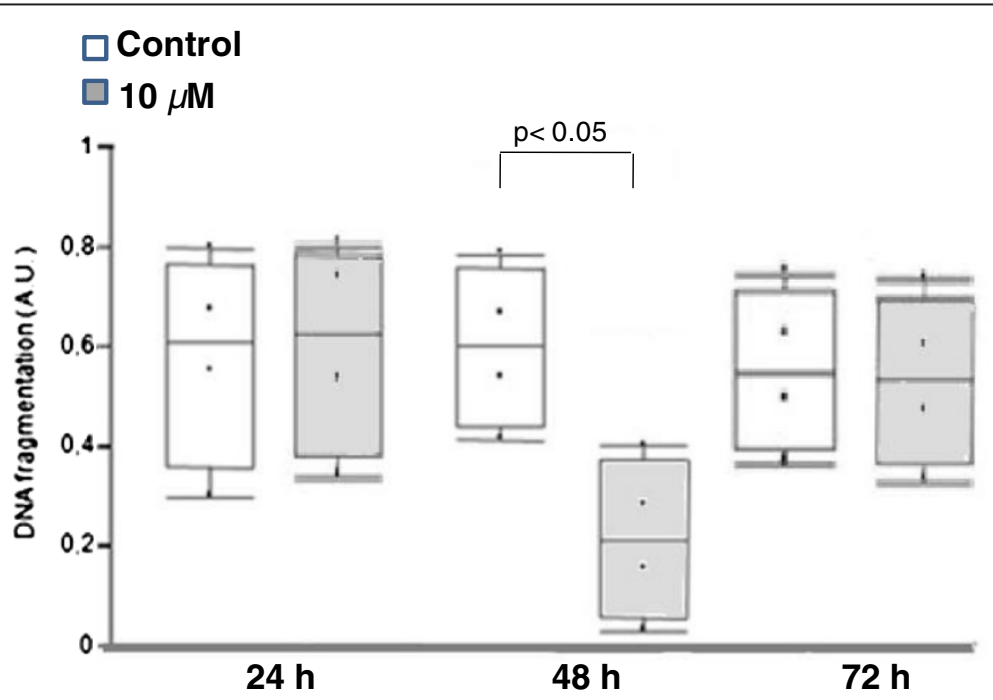

Figure 5 Apoptosis rate as measured by DNA fragmentation of islets exposed to Pioglitazone at physiological glucose concentration. Box diagram comparing islet treated by Pioglitazone $(10 \mu \mathrm{M})$ with non-treated cells (Control). The horizontal line within the box plot represents the median value, the box plot limits refer to $25^{\text {th }}$ to $75^{\text {th }}$ percentiles, and the box plot bars include the 10th to 90th percentiles for apoptosis rate. 


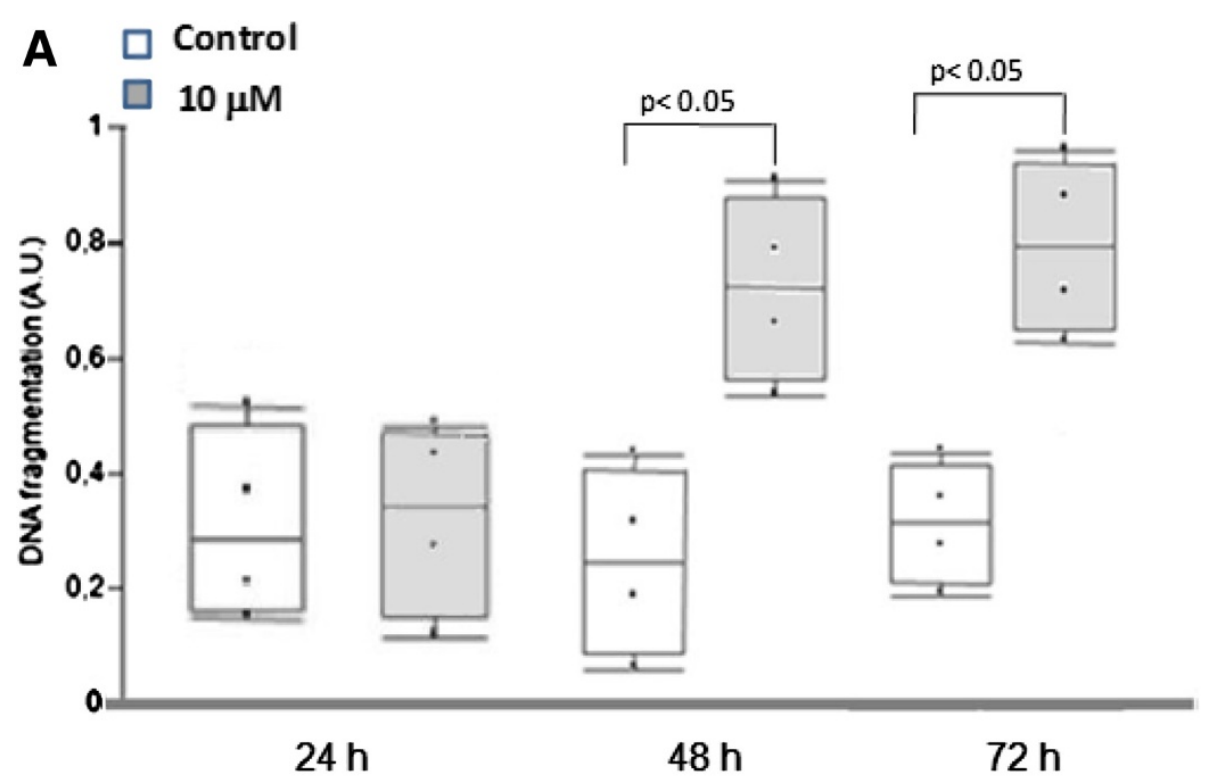

B

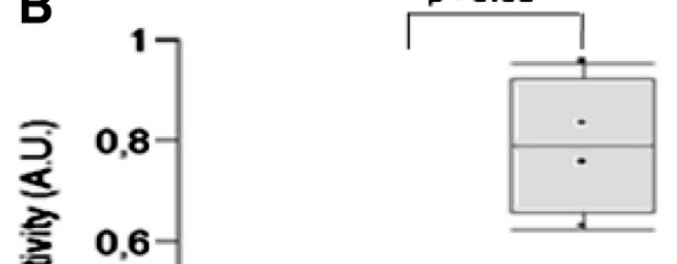

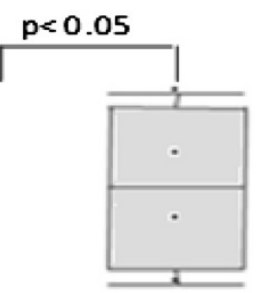

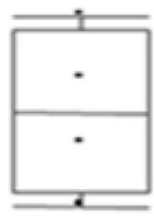

$72 \mathrm{~h}$

Figure 6 Apoptosis rate as measured by DNA fragmentation (Panel A) and by caspase 3 activity (Panel B) of islets exposed to Pioglitazone at supraphysiological glucose concentration. Box diagram comparing islet treated by Pioglitazone (10 $\mu \mathrm{M})$ with non-treated cells (Control). The horizontal line within the box plot represents the median value, the box plot limits refer to 25th to 75th percentiles, and the box plot bars include the 10th to 90th percentiles for apoptosis rate.

observed only when islets overexpressing PPAR- $\gamma$ were treated with GW-347845. Our current finding, in which 101 out of 13,059 genes were affected by Pioglitazone in islets maintained at $5.6 \mathrm{mM}$ glucose, suggests that gene expression in $\beta$-cells is not very sensitive to TZDs in euglycemic conditions and in cells with physiological expression of PPAR- $\gamma$. A further similarity between both studies was the lack of modulation of the genes coding for glucokinase and UCP2, previously suggested as PPAR- $\gamma$ targets $[29,30]$.

At both glucose concentrations Pioglitazone increased the expression of $S c d 2$ and Fabp4, lipogenic genes which are PPAR- $\gamma$ targets in adipocytes [31,32] and Srebf1, a transcription factor involved in lipogenesis in adipocytes
[33]. In the opposite metabolic direction, Pioglitazone increased the expression of Insig1 (at $5.6 \mathrm{mM}$ ), a protein that participates in the inhibition of cholesterol synthesis [34] and of Lipe (at $23 \mathrm{mM}$ ), which codes for hormonesensitive lipase, responsible for hydrolysis of triglycerides [35]. Thus, in conditions of physiological expression of PPAR- $\gamma$, Pioglitazone stimulates expression of genes that limit lipid accumulation in islets, but we cannot rule out that these changes are a response to a primary activation of lipogenic pathways, which is more concordant with the role of PPAR- $\gamma$ in other tissues.

The transcriptional response to Pioglitazone was strikingly different under conditions of elevated glucose, an effect not previously described. Concomitant treatment 
of islets with Pioglitazone and $23 \mathrm{mM}$ glucose increased by 12 -fold the number of modulated genes. Little is known about the mechanisms involved in glucose regulation of $\beta$-cell gene expression. It has been suggested that glucose metabolism alters gene expression directly at the transcriptional level by interfering with proteins bound to the preinitiation complex or by modifying the concentrations of transcription factors [36]. Although further studies are necessary to determine the contribution of enhanced RNA stability or direct transcriptional activation on the observed response, it can be hypothesized that at high concentrations, glucose interferes with ligand-dependent PPAR- $\gamma$ transcriptional activity, directly modulating the expression of genes that are not affected when islets are exposed solely to the PPAR- $\gamma$ ligand. However, since the transcriptional response to Pioglitazone was determined after $24 \mathrm{~h}$ in the absence of protein synthesis inhibitors, it is likely that part of the observed gene regulation is not directly due to ligand binding to PPAR- $\gamma$, but resulted from changes in expression of other transcriptional regulators targeted by the combination of glucose and ligand. It is also worth mention that both high glucose concentrations [37] and PPAR ligands [38] promote chromatin remodeling and transcription, which could also contribute to the observed finding.

At $48 \mathrm{~h}$, Pioglitazone elicited a reduction in islets apoptosis rate at $5.6 \mathrm{mM}$ glucose. The transient nature of this response makes it difficult to state that this TZD exerts a protective effect on pancreatic islets, but one can conclude that in such experimental condition, Pioglitazone is not deleterious, a result in contrast to that obtained at supraphysiological glucose concentration, at which an increased apoptosis rate was found after 48 and $72 \mathrm{~h}$. This pro-apoptotic tendency was also revealed by the gene expression analysis after $24 \mathrm{~h}$, since genes related to cell cycle and cell death were significantly modulated. Because genes related to lipid metabolism were also modulated at $5.6 \mathrm{mM}$, this single pathway does not seem to be related to the apoptotic fate of islets. Additional data that reinforce a proapoptotic trend of islets exposed to Pioglitazone at 23 $\mathrm{mM}$ glucose are upregulation of antioxidant defense genes such as Hmox1 and Sod2, believed to be activated, respectively, in response to cellular stress [39] and in ß-cell defense [40], and a lower Bcl2 RNA expression after 48 and $72 \mathrm{~h}$ of exposure. Although several studies have already demonstrated that TZD's may counteract direct fatty acid induced deleterious effects on $\beta$-cell function [11,41-44], few studies addressed the direct effects of TZD's in conditions mimicking hyperglycemia. Zeender et al. had found that Pioglitazone decreased the apoptosis rate of human islets exposed to $33.3 \mathrm{mM}$ glucose after $48 \mathrm{~h}(5 \mu \mathrm{M})$ and $96 \mathrm{~h}(1 \mu \mathrm{M})$ while Saitoh et al. did not observe any effect of Pioglitazone on the apoptotic rate of MIN-6 cells exposed to $25 \mathrm{mM}$ glucose [11] and Ohtani et al. found that troglitazone $\left(10^{-4}\right.$ to $10^{-6} \mathrm{M}$ ) induced apoptosis on HIT-15 cell exposed to 7 $\mathrm{mM}$ glucose for $72 \mathrm{~h}$ [45]. Reasons for the discrepancies between the studies might be the use of different experimental conditions such as glitazones and glucose concentrations, different cell lines or islets from different species, but the controversial results point out the need for further research on this issue.

It is probable that in vivo the indirect beneficial effects of TZDs on islets compensate for the potential deleterious direct effects in the presence of high glucose, given that previous studies have already demonstrated restoration of islet function in rodents $[7,8]$ and humans [4-6]. Furthermore, besides hyperglycemia, other conditions not addressed in this study participate in the loss of $\beta$-cell observed in type 2 diabetes, and there are reports supporting a protective effect of TZDs in presence of lipotoxicity [44,46,47], deposition of islet amyloid [48] and endoplasmic reticulum stress [38]. In agreement with the present study, however, a former in vitro study has already found that troglitazone protective effects on islets were less pronounced at high glucose [49].

In summary, our data demonstrate for the first time that the effect of Pioglitazone on pancreatic islet gene expression profile and apoptosis rate depends on the glucose concentration, reinforcing the necessity of additional studies designed to evaluate TZDs effects on the preservation of $\beta$-cell function in situations where glucotoxicity might be more relevant than lipotoxicity.

\section{Additional files}

Additional file 1: Table S1. Primers used in the qRT-PCR assays.

Additional file 2: Table S2. List of genes which were down- and up-regulated by Pioglitazone in islets maintained at physiological glucose concentration (5.6 mM).

Additional file 3: Table S3. List of the first 200 genes which were down- and up-regulated by Pioglitazone in islets maintained at supraphysiological glucose concentration ( $23 \mathrm{mM}$ ).

\section{Abbreviation}

TZD: Thiazolidinedione.

Competing interests

No potential conflict of interest relevant to this article is reported.

Authors' contributions

RNL performed microarray and RT-PCR experiments, CNC performed apoptosis and insulin secretion experiments, PW provided input into the design of the study and performed microarray statistical analysis; FLC and LSO helped in islet isolation; DGN provided input into the design of the study and performed statistical analysis; KHK participated in the design, helped funding the study and revised the manuscript; MLCG participated in the design of the study, obtained funding and wrote the manuscript. All authors read and approved the final manuscript. 


\section{Acknowledgments}

This work was supported by grants from NIDDK (UO1 DK 56947; P30 DK 19525) and from FAPESP (04/01816-5, 04/01467-0 and 04/10797-4). The authors are grateful to Takeda Chemicals Industries (Japan) for supplying pioglitazone hydrochloride pure substance.

\section{Author details}

${ }^{1}$ Laboratory for Cellular and Molecular Endocrinology LIM-25, University of Sao Paulo Medical School, Av. Dr. Arnaldo 455 \#4305, 01246-903, São Paulo, Brazil. '2Department of Genetics and Institute for Diabetes, Obesity and Metabolism, University of Pennsylvania School of Medicine, 752B CRB 415 Curie Blvd., Philadelphia, Pennsylvania 19104, USA. ${ }^{3}$ Laboratory Medicine, University of Santo Amaro, Sao Paulo, Brazil. ${ }^{4}$ Postgraduate Program in Medicine, Universidade Nove de Julho - Uninove, Sao Paulo, Brazil.

Received: 29 February 2012 Accepted: 6 December 2012

Published: 8 January 2013

\section{References}

1. Kahn SE: The relative contributions of insulin resistance and beta-cell dysfunction to the pathophysiology of Type 2 diabetes. Diabetologia 2003, 46:3-19.

2. Weyer C, Bogardus C, Mott DM, Pratley RE: The natural history of insulin secretory disfunction and insulin resistance in the pathogenesis of type 2 diabetes mellitus. J Clin Invest 1999, 104:787-794.

3. Zangeneh F, Kudva YC, Basu A: Insulin Sensitizers. Mayo Clin Proc 2003, 78:471-479.

4. Buchanan TA, Xiang AH, Peters RK, Kjos SL, Marroquin A, Goico J, Ochoa C, Tan S, Berkowitz K, Hodis HN, Azen SP: Preservation of Pancreatic $\beta$-Cell Function and Prevention of Type 2 Diabetes by Pharmacological Treatment of Insulin Resistance in High-Risk Hispanic Women. Diabetes 2002, 51:2796-2803.

5. Miyazaki CY, Matsuda M, DeFronzo R: Dose-response effect of pioglitazone on insulin sensitivity and insulin secretion in type 2 diabetes. Diabetes Care 2002, 25:517-523.

6. Smith SA, Porter LE, Biswas N, Freed MI: Rosiglitazone, but not glyburide, reduces circulating proinsulin and the proinsulin:insulin ratio in type 2 diabetes. J Clin Endocrinol Metabol 2004, 89:6048-6053.

7. Finegood DT, McArthur MD, Kojwang D, Kojwang D, Thomas MJ, Topp BG, Leonard T, Buckingham RE: Cell mass dynamics in Zucker diabetic fatty rats: rosiglitazone prevents the rise in net cell death. Diabetes 2001, 50:1021-1029.

8. Higa M, Zhou YT, Ravazzola M, Baetens D, Orci L, Unger RH: Troglitazone prevents mitochondrial alterations, beta cell destruction, and diabetes in obese prediabetic rats. Proc Natl Acad Sci 1999, 96:11513-11518.

9. Matsui J, Terauchi Y, Kubota N, Takamoto I, Eto K, Yamashita T, Komeda K, Yamauchi T, Kamon J, Kita S, Noda M, Kadowaki T: Pioglitazone reduces islet triglyceride content and restores impaired glucose-stimulated insulin secretion in heterozygous peroxisome proliferator-activated receptor gamma- deficient mice on a high-fat diet. Diabetes 2004 53:2844-2854.

10. Shimabukuro M, Zhou $Y$, Lee $Y$, Unger RH: Troglitazone lowers islet fat and restores beta cell function of Zucker diabetic fatty rats. J Biol Chem 1998 273(6):3547-3550

11. Saitoh Y, Chun-ping C, Noma K, Ueno H, Mizuta M, Nakazato M: Pioglitazone attenuates fatty acid-induced oxidative stress and apoptosis in pancreatic beta-cells. Diabetes Obes Metab 2008, 10(7):564-573.

12. Butler AE, Janson J, Bonner-Weir S, Ritzel R, Rizza RA, Butler PC: Beta-cell deficit and increased beta-cell apoptosis in humans with type 2 diabetes. Diabetes 2003, 52:102-110.

13. Kashyap S, Belfort R, Castaldelli A, Pratipanawatr T, Berria R, Pratipanawatr W, Bajaj M, Mandarino L, DeFronzo R, Cusi K: A sustained increase in plasma free fatty acids impairs insulin secretion in nondiabetic subjects genetically predisposed to develop type 2 diabetes. Diabetes 2003 , 52:2461-2474

14. Campbell IW, Mariz S: Beta-cell preservation with thiazolidinediones. Diabetes Res Clin Pract 2007, 76:163-176.

15. Zeender E, Maedler K, Bosco D, Berney T, Donath MY, Halban PA: Pioglitazone and sodium salicylate protect human beta-cells against apoptosis and impaired function induced by glucose and interleukin1beta. J Clin Endocrinol Metabol 2004, 89:5059-5066.
16. Chung SS, Kim M, Lee JS, Ahn BY, Jung HS, Lee HM, Park KS: Mechanism for antioxidative effects of thiazolidinediones in pancreatic $\beta$-cells. Am J Physiol Endocrinol Metab 2011, 301(5):E912-E921.

17. Kono T, Ahn G, Moss DR, Gann L, Zarain-Herzberg A, Nishiki Y, Fueger PT, Ogihara T, Evans-Molina C: PPAR- $\gamma$ activation restores pancreatic islet SERCA2 levels and prevents $\beta$-cell dysfunction under conditions of hyperglycemic and cytokine stress. Mol Endocrinol 2012, 26(2):257-271.

18. Cnop M, Hannaert JC, Pipeleers DG: Troglitazone does not protect rat pancreatic $\beta$ cells against free fatty acid-induced cytotoxicity. Biochem Pharmacol 2002, 63:1281-1285.

19. Nakamichi Y, Kikuta T, Ito E, Ohara-Imaizumi M, Nishiwaki C, Ishida H, Nagamatsu S: PPAR-gamma overexpression suppresses glucose-induced proinsulin biosynthesis and insulin release synergistically with pioglitazone in MIN6 cells. Biochem Biophys Res Commun 2003, 306(4):832-836.

20. Lacy PE, Kostianovsky M: Method for the isolation of intact islets of Langerhans from the rat pancreas. Diabetes 1967, 16:35-39.

21. White P, Brestelli JE, Kaestner KH, Greenbaum LE: Identification of transcriptional networks during liver regeneration. J Biol Chem 2005, 280:3715-3722.

22. Kaestner KH, Lee CS, Scearce LM, Brestelli JE, Arsenlis A, Le PP, Lantz KA Crabtree J, Pizarro A, Mazzarelli J, Pinney D, Fischer S, Manduchi E, Stoeckert CJ Jr, Gradwohl G, Clifton SW, Brown JR, Inoue H, Cras-Méneur C, Permutt MA Transcriptional Program of the Endocrine Pancreas in Mice and Humans. Diabetes 2003, 52:1604-1610.

23. Smyth GK: Linear Models and Empirical Bayes Methods for Assessing Differential Expression in Microarray Experiments. Stat Appl Genet Mol Biol 2004, 3(1). Article 3. Available at: http://www.bepress.com/sagmb/vol3/iss1/ art3. (Accessed on December, 15th, 2007).

24. Tusher VG, Tibshirani R, Chu G: Significance analysis of microarrays applied to the ionizing radiation response. Proc Natl Acad Sci U S A 2001 98(9):5116-5121.

25. Manduchi E, Grant GR, He H, Liu J, Mailman MD, Pizarro AD, Whetzel PL, Stoeckert CJ Jr: RAD and the RAD Study-Annotator: an approach to collection, organization and exchange of all relevant information for highthroughput gene expression studies. Bioinformatics 2004, 20(4):452-459.

26. Vandesompele J, De Preter K, Pattyn F, Poppe B, Van Roy N, De Paepe A Speleman F: Accurate normalization of real-time quantitative RT-PCR data by geometric averaging of multiple internal control genes. Genome Biol 2002, 3(7):research0034.1-research0034.11.

27. Livak KJ, Schmittgen TD: Analysis of relative gene expression data using real-time quantitative PCR and the 2 Delta Delta C T method. Methods 2001, 25:402-408.

28. Parton LE, Diraison F, Neill SE, Ghosh SK, Rubino MA, Bisi JE, Briscoe CP, Rutter GA: Impact of PPARgamma overexpression and activation on pancreatic islet gene expression profile analyzed with oligonucleotide microarrays. Am J Physiol Endocrinol Metab 2004, 287(3):E390-E404.

29. Kim HI, Cha JY, Kim SY, Kim JW, Roh KJ, Seong JK, Lee NT, Choi KY, Kim KS, Ahn YH: Peroxisomal Proliferator-Activated Receptor- $\gamma$ Upregulates Glucokinase Gene Expression in $\beta$-cells. Diabetes 2002, 51:676-685.

30. Tian JY, Li G, Gu YY, Zhang HL, Zhou WZ, Wang X, Zhu HD, Luo TH, Luo M: Role and mechanism of rosiglitazone on the impairment of insulin secretion induced by free fatty acids on isolated rat islets. Chin Med J 2006, 119(7):574-580.

31. Risérus U, Tan GD, Fielding BA, Neville MJ, Currie J, Savage DB, Chatterjee VK, Frayn KN, O'Rahilly S, Karpe F: Rosiglitazone increases indexes of stearoyl-CoA desaturase activity in humans: link to insulin sensitization and the role of dominant-negative mutation in peroxisome proliferator-activated receptorgamma. Diabetes 2005, 54(5):1379-1384

32. Spiegelman BM, Flier JS: Adipogenesis and Obesity: Rounding Out the Big Picture. Cell 1996, 87:377-389.

33. Fajas L, Schoonjans K, Gelman L, Kim JB, Najib J, Martin G, Fruchart JC, Briggs M, Spiegelman BM, Auwerx J: Regulation of Peroxisome Proliferator-Activated Receptor g Expression by Adipocyte Differentiation and Determination Factor 1/Sterol Regulatory Element Binding Protein 1: Implications for Adipocyte Differentiation and Metabolism. Molecular Cell Biology 1999, 19(8):5495-5503

34. Yang T, Espenshade PJ, Wright ME, Yabe D, Gong Y, Aebersold R, Goldstein JL, Brown MS: Crucial Step in Cholesterol Homeostasis: Sterols Promote Binding of SCAP to INSIG-1, a Membrane Protein that Facilitates Retention of SREBPS in ER. Cell 2002, 110:489-500. 
35. Peyot ML, Nolan CJ, Soni K, Joly E, Lussier R, Corkey BE, Wang SP, Mitchell GA, Prentki M: Hormone-Sensitive Lipase Has a Role in Lipid Signaling for Insulin Secretion but Is Nonessential for the Incretin Action of Glucagon-Like Peptide 1. Diabetes 2004, 53:1733-1742

36. Schuit F, Flamez D, De Vos A, Pipeleers D: Glucose-Regulated Gene Expression Maintaining the Glucose-Responsive State of $\beta$-Cells. Diabetes 2002, 51(Suppl. 3):S326-S332.

37. Miao F, Gonzalo IG, Lanting L, Natarajan R: In vivo chromatin remodeling events leading to inflammatory gene transcription under diabetic conditions. J Biol Chem 2004, 279(17):18091-18097.

38. Evans-Molina C, Robbins RD, Kono T, Tersey SA, Vestermark GL, Nunemaker CS, Garmey JC, Deering TG, Keller SR, Maier B, Mirmira RG: Peroxisome proliferatoractivated receptor gamma activation restores islet function in diabetic mice through reduction of endoplasmic reticulum stress and maintenance of euchromatin structure. Molecular Cell Biology Apr 2009, 29(8):2053-2067.

39. Ryter SW, Alam J, Choi AM: Heme oxygenase-1 carbon monoxide: from basic science to therapeutic applications. Physiol Rev 2006, 86:583-650

40. Eizirik DL, Sandler S, Palmer JP: Repair of pancreatic B-cells: a relevant phenomenon in early IDDM. Diabetes 1993, 42:1383-1389.

41. Abaraviciene SM, Lundquist I, Salehi A: Rosiglitazone counteracts palmitate-induced beta-cell dysfunction by suppression of MAP kinase, inducible nitric oxide synthase and caspase 3 activities. Cell Mol Life Sci 2008, 65(14):2256-2265.

42. Ghanaat-Pour H, Sjöholm A: Gene expression regulated by pioglitazone and exenatide in normal and diabetic rat islets exposed to lipotoxicity. Diabetes \& Metabolism Rev 2009, 25(2):163-184.

43. Lupi R, Del Guerra S, Marselli L, Bugliani M, Boggi U, Mosca F, Marchetti P, Del Prato S: Rosiglitazone prevents the impairment of human islet function induced by fatty acids: evidence for a role of PPARgamma in the modulation of insulin secretion. Am J Physiol Endocrinol Metab 2004, 286(4):E560-E567.

44. Vandewalle B, Moerman E, Lefebvre B, Defrance F, Gmyr V, Lukowiak B, Kerr Conte J, Pattou F: PPARgamma-dependent and -independent effects of rosiglitazone on lipotoxic human pancreatic islets. Biochem Biophys Res Commun 2008, 366(4):1096-1101.

45. Ohtani Kl, Shimizu H, Sato N, Mori M: Troglitazone (CS-045) inhibits betacell proliferation rate following stimulation of insulin secretion in HIT-T 15 cells Endocrinology. Jan 1998, 139(1):172-178.

46. Kanda Y, Shimoda M, Hamamoto S, Tawaramoto K, Kawasaki F, Hashiramoto M, Nakashima K, Matsuki M, Kaku K: Molecular mechanism by which pioglitazone preserves pancreatic beta-cells in obese diabetic mice: evidence for acute and chronic actions as a PPARgamma agonist. Am J Physiol Endocrinol Metab 2010, 298(2):E278-E286.

47. Pickavance LC, Widdowson PS, Foste JR, Williams G, Wilding JPH: Chronic treatment with the thiazolidinedione, MCC-555, is associated with reductions in nitric oxide synthase activity and $\beta$-cell apoptosis in the pancreas of the Zucker Diabetic Fatty rat. Int J Exp Pathol 2003, 84:83-89.

48. Lin CY, Gurlo T, Haataja L, Hsueh WA, Butler PC: Activation of Peroxisome Proliferator-Activated Receptor- $\gamma$ by Rosiglitazone Protects Human Islet Cells against Human Islet Amyloid Polypeptide Toxicity by a Phosphatidylinositol 3-Kinase-Dependent Pathway. J Clin Endocrinol Metabol 2005, 90(12):6678-6686.

49. Bollheimer LC, Troll S, Landauer H, Wrede CE, Schölmerich J, Buettner R: Insulin-sparing effects of roglitazone in rat pancreatic islets. J Mol Endocrinol 2003, 31(1):61-69.

doi:10.1186/1758-5996-5-1

Cite this article as: Lamounier et al:: Apoptosis rate and transcriptional response of pancreatic islets exposed to the PPAR gamma agonist Pioglitazone. Diabetology \& Metabolic Syndrome 2013 5:1.

\section{Submit your next manuscript to BioMed Central and take full advantage of:}

- Convenient online submission

- Thorough peer review

- No space constraints or color figure charges

- Immediate publication on acceptance

- Inclusion in PubMed, CAS, Scopus and Google Scholar

- Research which is freely available for redistribution

Submit your manuscript at www.biomedcentral.com/submit
C Biomed Central 